\title{
Bridging the Peace Gap in Nigeria: The Panel of the Wise as a Constitutional Essential
}

\author{
Ademola Oluborode Jegede*
}

\begin{abstract}
Since the return to democratic governance in 1999, violent conflicts around identities including religion, ethnicity, indigene/settler differentiation and resource control remain a challenge to peace in Nigeria. Thus far, responses of government lack a normative framework to motivate consistent intervention and foster peace. While the 1999 Constitution identifies peace as a common aspiration, there is a deficit of a non-adversarial institutional mechanism to address violent identity related conflicts in Nigeria. Despite its limited relevance, the visible institution for conflict management is the court. This article argues the need for the establishment of a panel of the wise, a conflict and peace intervention mechanism, as an "essential" for Nigerian constitution. It then explores key considerations in terms of the composition, functions and legal status of intervention of the proposed panel for the management of violent conflicts associated with identity and fostering peace in Nigeria.
\end{abstract}

\section{INTRODUCTION- THE PEACE CHALLENGE IN NIGERIA}

Despite the optimism on its return to democratic governance in 1999, Nigeria is still a divided society plagued by insecurity and dwindling peace. It faces the peace challenge, not only in the sense of the presence of intense and violent conflicts in some of its parts, but in the absence of adequate structures that prevent violent conflicts and advance equality and security. ${ }^{1}$ At the heart of the challenge is conflict of identities including religion, ethnicity and indigene/settler distinction which has become a seedbed of tension, violence and insurgency in Nigeria. ${ }^{2}$ Yet,

\footnotetext{
* LLB (Hons) (Ife), LLM (Pretoria), MPH (Ibadan), BL (Nigerian Law School); LLD (Human Rights) candidate and tutor, Centre for Human Rights, University of Pretoria, ademolajegede@gmail.com.

${ }^{1}$ There are different school of thoughts on the concept of peace: the Pax Romania concept which views peace as absence of war - this has been criticised for its neglect of issues which cause violence to flourish, the Graeco-Arabic-Hebraic, and the Eirene-sala'am-shalom notions which respectively embodies ideas of justice, equity and freedom while the Hindu-Jainist-Buddhist traditions of shanti emphasise intra-personal peace and harmony with nature, see D Oyesola "Environmental degradation and peace studies" in IO Albert (ed) Perspectives on Peace and Conflict in Africa (2005, Peace and Conflict Studies Programme) at 253-267. On the need for structural changes in addressing peace and security challenges facing Nigeria, see EO Alemika "Ethnicity and ethnic conflicts in Nigeria" in DA Guobadia and AO Adekunle (eds) Ethnicity and National Integration in Nigeria: Recurring Theme (2004, Nigerian Institute of Advanced Legal Studies) at 87-108.

${ }^{2}$ Identity refers to the way individuals and groups identify themselves or are identified by others, see generally, A Gutman Identity in Democracy (2003, Princeton University Press) at 1-37. On the literature linking identity with politics and violent conflicts, see generally G Hagg and P Kagwanja "Identity and peace: Reconfiguring conflict resolution in Africa" (2007) 7(2) African Journal on Conflict Resolution 9. See also Gutman Identity in Democracy, above at note 2. In relation to scholarship focusing on identity and violent conflict in Nigeria, see J Nwanegbo, J Odigbo and NC Ochanja "Citizenship, indigeneship and settlership crisis in Nigeria: Understanding the dynamics of Wukari crisis" (2014) 4(1)
} 
conflict of identities in itself is neither a negative force or harmful. ${ }^{3}$ It is either a building or stumbling block in the development of a state. ${ }^{4}$ As Galtung notes, although conflict connotes the idea of two or more incompatible goals, conflict behaviour is not necessarily harmful. ${ }^{5}$ Nevertheless, if managed ineffectively, conflict behaviour becomes destructive resulting in "Hobbesian state of affairs where everybody uses all possible means of destruction against everybody else". ${ }^{6}$ Equally, when politicised through the promotion of "negative stereotypes", 7 identity conflicts can escalate into armed hostilities and undermine peace. ${ }^{8}$ This is indeed the case with Nigeria as seen in the insurgency of Boko Haram (meaning western education is sinful), which is engulfing different states in the northern part of the country ${ }^{9}$; ethnicity and indigene/settler question as evident in Tiv-Jukun, ${ }^{10}$ and Ezza-Ezillo, ${ }^{11}$ Ife-Modakeke, ${ }^{12}$ JosKaduna $^{13}$ communities crises; and natural resources interlinked with ethnic and indigene/settler questions as discernible from Ijaw-Ilaje, ${ }^{14}$ Urhobo-Itshekiri, ${ }^{15}$ and Niger- Delta situations. ${ }^{16}$

The contribution of identity to the fragility of peace and the uncertainty of unity in Nigeria has attracted the attention of commentators and researchers. Identities such as religion and ethnicity, Igbokwe comments, are usually serviced as instruments of war. ${ }^{17}$ Reflecting on the agitation emanating from identity around oil resources and squander by political elite, Fasan questions if there would ever be peace in Nigeria again. ${ }^{18}$ While imaging the manipulation of ethnicity, religion and oil politics in Nigeria, Soyinka points out that "we may actually be witnessing a nation at the verge of extinction". ${ }^{19}$ Considering the challenges that confront the nation, Maier admits Nigeria is shaking but cautions that it cannot be ignored because if it falls, it will "shake the rest of West Africa" ${ }^{20}$

Journal Research in Peace, Gender and Development at 8-14. See also O Obafemi and H Galadima (eds) Complex Insurgencies in Nigeria: Proceedings of the NIPSS 2012 Eminent Persons \& Experts Group Meeting (2013, National Institute for Policy and Strategic Studies).

${ }^{3}$ Gutman Identity in Democracy, above at note 2 at 3.

${ }_{5}^{4}$ CH Enloe Ethnic Conflict and Political Development (1973, Little, Brown and Company) at 3.

${ }^{5} \mathrm{~J}$ Galtung "Institutionalized conflict resolution: A theoretical paradigm" (1965) 2(4) Journal of Peace Research 348, at 349.

${ }^{6}$ Ibid.

${ }^{7}$ Gutman Identity in Democracy, above at note 2 at 7.

${ }^{8}$ C Igbokwe "Nigeria 2015: Servicing the instruments of war" (6 August 2014) Aljazeera, available at:

<http://www.aljazeera.com/indepth/opinion/2014/08/nigeria-2015-servicing-instrument-2014867485504717.html> (last accessed 4 September 2014).

${ }^{9}$ AU Adamu "Insurgency in Nigeria: The northern Nigerian experience" in Obafemi and Galadima (eds) Complex Insurgencies in Nigeria, above at note 2 at 77-139. See also A Okpaga, US Chijioke and EO Innocent "Activities of Boko Haram and the insecurity question in Nigeria" (2012) 1(9) Arabian Journal of Business and Management Review 77.

${ }^{10} \mathrm{R}$ Ciboh "Newspaper inquest into Tiv-Jukun Conflict 2001: An analysis of ethnic inequality and domination in contemporary Nigeria" (2014) 21 New Media and Mass Communication 40 at 42-43.

${ }^{11} \mathrm{P}$ Mbah and C Nwangwu "Sub-ethnic identity and conflict in Nigeria: The policy option for the resolution of the conflict between Ezza and Ezillo in Ebonyi State" (2014) 5 (2) Mediterranean Journal of Social Sciences 681.

${ }^{12}$ OO Akanji "Group rights and conflicts in Africa: A critical reflection on Ife-Modakeke, Nigeria" (2009) 16 International Journal on Minority and Group Rights 31.

${ }^{13}$ SO Uhunmwuangho and A Epelle "Challenges and solutions to ethno-religious conflicts in Nigeria: Case study of the Jos crises" (2011) 13(5) Journal of Sustainable Development in Africa 109.

${ }^{14}$ OO Christopher "Communal conflict management, information communication and utilization in Ondo State, Nigeria: A case study of Ijaw/Ilaje Crises" (2008) 5(1 \&2) Journal of Library and Information Science 141.

${ }^{15}$ AO Anthony "An evaluation of the causes and efforts adopted in managing the ethnic conflicts, identity and settlement pattern among the different ethnic groups in Warri, Delta State, Nigeria” (2014) 3(4) International Journal of Science and Research 344 at 346.

${ }^{16}$ NS Akpan "Governance and communal conflicts in a post-democratic Nigeria: A case of the oil-producing Niger Delta Region" (2010) 2(3) Journal of African Studies and Development 65.

${ }^{17}$ Igbokwe "Nigeria 2015", above at note 8.

${ }^{18}$ R Fasan "Will there be peace in our time?" (28 September 2011) Vanguard (Nigeria) at 36.

${ }^{19}$ W Soyinka The Open Sore of a Continent: A Personal Narrative of the Nigerian Crisis (1996, Oxford University Press) at 18.

${ }^{20}$ K Maier This House Has Fallen: Crisis in Nigeria (2000, Penguin) at xix. See also J Campbell Nigeria: Dancing on the Brink (2011, Rowman and Littlefield). 
Similar to Maier's position, the disintegration of Nigeria, the largest political concentration of African people in the continent, argues Onwudiwe, will pose strategic danger to Africa's expected rebirth. ${ }^{21}$

To be fair, the government is not completely lethargic in the face of grave challenges which threaten the peace and stability of the nation. For instance, in recent time, efforts have been made to address the Niger-Delta conflict through developmental programs packaged under the amnesty initiative since $2009 .{ }^{22}$ However, renewed insurgence in the Niger-Delta region raises doubts about the success of the initiative. ${ }^{23}$ In similar regard, there have been activities on the part of the state and civil society which are geared toward addressing the Jos/Plateau conflicts. ${ }^{24}$ Also, the federal government, through offices such as National Security Adviser (NSA), State Security Service (SSS), the Defence Intelligence Agency (DIA), and the Nigerian Intelligence Agency (NIA) were once involved in a proposed negotiation with representatives of the Boko Haram. ${ }^{25}$ The government called a national conference to exchange ideas and thoughts on issues and make recommendations to advance national unity. ${ }^{26}$ Criticised as it is as a share waste of public fund, issues on the agenda of the national conference included potential sources of intense violence and insurgency: revenue sharing, resource control, state and local government creation, boundary adjustment, and indigeneship. ${ }^{27}$

However, the above efforts by the state to tackle the sources of recurring violent conflicts portray an approach that denies the reality of a structural problem which cannot be addressed as a one off-event. ${ }^{28}$ The approach lacks a legal basis or framework to motivate a consistent management of identity related conflicts and foster peace in Nigeria. In particular, the 1999 Constitution which though identifies peace and stability as a common aspiration of the state ${ }^{29}$ lacks a non-adversarial mechanism that can intervene to prevent or mediate identity based issues before they morph into violent or full blown armed conflicts. Rather, what is visible is the court, which is generally vested with the power to adjudicate disputes arising from legal right, duty, liability, privilege, interest, obligation or claim is in issue. ${ }^{30}$ Yet, a sole reliance on the court ignores its limitation in promoting peace and security. ${ }^{31}$ It contrasts with the view of Ogunyemi, calling for an expansion of "people's choices in every relevant way" in order to tackle security challenge in Nigeria. ${ }^{32}$ It betrays the reality that violent conflicts arising from clash

\footnotetext{
${ }^{21}$ E Onwudiwe "A pan-African agenda for the national conference", available at: <http://www.utexas.edu/conferences/africa/ads/371.html > (last accessed 4 September 2014).

${ }^{22}$ DA Amaraegbu "Violence, terrorism and security threat in Nigeria's Niger Delta: An old problem taking a new dimension" (2011) 5(4) African Journal of Political Science and International Relations 208 at 209.

23 Ibid.

${ }^{24}$ I Osareti and E Akov "Ethno-religious conflict and peace building in Nigeria: The case of Jos, Plateau State" (2013) 2(1) Academic Journal of Interdisciplinary Studies 349 at 355. See also News Agency of Nigeria (NAN) "Jonathan, Hausa / Fulani leaders meet over Jos crises" (12 August 2012) Vanguard (Nigeria).

${ }^{25}$ O Adetayo "Presidency considers Boko-Haram Terms" (19 August 2012) Punch (Nigeria).

${ }^{26}$ E Embu "FG releases delegates lists for national confab" (6 March 2014) Daily Times (Nigeria).

${ }^{27}$ Online and New Media "National Conference, a waste of public funds -Poll" (17 April 2014) Punch (Nigeria).

${ }^{28}$ EB Mijah "Democracy, internal security and the challenges of policing in Nigeria" (paper presented at International Conference, Evangelische Akademie, Germany, 15-17 June 2007) at 10.

${ }^{29}$ Constitution of the Federal Republic of Nigeria 1999 (CAP C23 LFN 2004), sec 15 (1) describes the motto of the Federal Republic of Nigeria as "Unity and Faith, Peace and Progress".

${ }^{30}$ Id chap 7 generally describes the power of courts.

${ }^{31}$ MT Ladan "Diagnostic review of insurgency in Nigeria: The legal dimension" in Obafemi and Galadima (eds) Complex Insurgencies in Nigeria, above at note 2 at 28-31.

${ }^{32}$ B Ogunyemi "Our sense of security" (30 September 2011) ThisDay (Nigeria) at 34- 35.
} 
of identities are an integral part of Nigerian history. ${ }^{33}$ It leaves unexplored the position of Emelonye and Chukwumaeze that the constitution is a strong legal framework in the hand of a state to coordinate identity issues such as religion and cultural activities. ${ }^{34}$ Since a constitution should be open to a constant review, to help in resolving violent conflict associated with identities and fostering peace in the polity, should there be a constitutional recognition and role for a group of non-partisan eminent persons, referred to in this paper, as the panel of the wise?

The article makes a case for the establishment of a panel of the wise in the Nigerian constitution and for that purpose, explores salient considerations in terms of its composition, functions and legal status of intervention. Following this introduction, section two of the paper examines briefly whether an argument advancing an alternative conflict management mechanism such as "a panel of the wise" can be validly made within the concept of "constitutional essentials". Section three of the paper justifies the necessity of a panel of the wise as an "essential" in the Nigerian constitution. Section four explores key considerations in terms of composition, functions and legal status of intervention in establishing the proposed panel to manage identity-related violent conflicts and foster peace in Nigeria. Section five is the conclusion.

\section{CONSTITUTIONAL “ESSENTIALS”: AN ALTERNATIVE CONFLICT MANAGEMENT TOOL IN CONTEXT}

There has been scholarly attention on what a constitution should embody so as to aid the fulfilment of its role as a guide to governance in a democratic state. According to Rawls, "constitutional essentials" should reflect the fundamental principles that specify the general structure of government, political process, and the equal basic rights and liberties of citizenship that majorities are to respect. ${ }^{35}$ Michelman defines commitment to the implementation of rights and laws and their effective administration as "constitutional essentials" for a state. ${ }^{36}$ In Elster's view, "essentials" of constitutions should, at the very least, "define and protect the rights of the citizens" and "establish the machinery of government". ${ }^{37}$ Along similar lines, Rawls notes, the constitution, should contain arrangements which are appropriate for reconciling conflicting opinions about rights and justice. ${ }^{38}$

On the essential institutional framework for resolving conflicting opinions of rights and justice, interpretation of rights as well as the exercise of powers among organs of governance, the argument of Raz is instructive. Viewing the protection of basic rights as essential to protect "collective goods" ${ }^{39}$ which arguably include peace, ${ }^{40}$ Raz explains that the court is particularly competent to deal with conflict of rights affecting individuals and the functioning of organs of governance. ${ }^{41}$ The institutional case for the court as an appropriate forum to safeguard

\footnotetext{
${ }^{33}$ For general highlights on conflicts in Nigeria, see SG Egwu Ethnic and Religious Violence in Nigeria (2011, St. Stephen Inc. Book House). See also T Falola and MM Heaton A History of Nigeria (2008, Cambridge University Press).

${ }^{34} \mathrm{U}$ Emelonye and U Chukwumaeze "Constitutional development and legal frameworks in Nigeria" in U Emelonye and RM Buergenthal (eds) Nigeria: Peacebuilding through Integration and Citizenship (2011, International Development Law Organization) at 121.

${ }_{35}^{35}$ J Rawls Political Liberalism (2005, Columbia University Press) at 227.

${ }^{36}$ F Michelman "Constitutional Essentials" (Conference on the 20th Anniversary of Israel's Human Rights Revolution, 19 December 2011 ) at 6.

${ }^{37}$ J Elster "Constitutionalism in Eastern Europe" (1991) 58(2) The University of Chicago Law Review 447 at 465.

${ }^{38}$ Rawls Political Liberalism, above at note 35 at 197.

${ }^{39}$ Raz The Morality of Freedom (1988, Oxford University Press) at 258.

${ }^{40}$ B Møller "Peace as a global public good" (Development Research Series, Research Center on Development and International Relations, Working Paper No.127, 2004) at 6.

${ }^{41}$ Raz The Morality of Freedom, above at note 39 at 258.
} 
rights in protection of common goods rests on two contentions. First, litigation before the court is a channel of political action in solving intractable conflicts of individual rights. ${ }^{42}$ Second, courtrooms generally provide groups with "insufficient economic power", or "little social prestige", or "poor education", a forum which allows their voices to be heard. ${ }^{43}$

However, viewed from the lens of identity related violent conflicts, the reality about the process and outcome of the functioning of courts suggests that the above arguments in relation to the institutional role of courts are overrated. A reliance on the court for redressing violent conflicts associated with identities including religion, ethnicity and natural resources can be ineffectual. As Mamdani cautions, there is danger in focusing on courts as the primary custodian of justice in redressing identity issues. ${ }^{44}$ This is because identity questions are not always a question of "right against wrong" but one of "right against right", the determination of which courts are not the most appropriate fora. Whereas, courtrooms' rules allow for either a guilty or innocent verdict, in identity based violent conflicts, neither side is "wholly innocent or guilty". This is why a race identity conflicts such as apartheid, in Mamdani's view, did not end in the adversarial process of courts where "winners take all" but on the negotiation table. ${ }^{45}$ Besides, though the religious, ethnic and resource considerations that underlie conflicts can be formulated as legal issues, fundamentally these issues, and indeed the protagonists involved often have incompatible point of view about the status quo which may include existing law, rights and courtrooms. Hence, the management of such conflicts should anchor on a flexible and reconciliatory process other than the courtroom. This is more so as reconciliation is not the main end of courtroom adjudication. To be sure too, the position that courts litigation allows those who lack access to power an open forum for their voices to be heard ${ }^{46}$ is disputed. Courts do not intervene into disputes unless invited by parties, and generally, participants in destructive conflict mood or behaviour are the vulnerable, including youth, children and illiterate who may be unwilling or unable to access the courts or when they do, are dissatisfied with the outcome of its decisions. Indeed, the rules of procedure of courts, in terms of accessibility, may limit the scope for participation of these vulnerable groups. ${ }^{47}$ The difficulty in relying on the process and outcome of courts in relation to conflicts related to identity can be illustrated through examples from the functioning of courts of records and customary institutions in Nigeria.

\section{The limit of courts of records as an "essential" for resolving identity-based conflicts}

While the courts of records, that is, courts presided over by judges trained in law, ${ }^{48}$ are an indispensable institution for conflict resolution and justice in Nigeria, ${ }^{49}$ their adversarial process and resulting outcome are a major limitation on their use as an effective option for resolving violent conflicts associated with identity. There are several experiences which can be urged in explanation, however, this point is brought out with more particular clarity by

\footnotetext{
42 J Raz "Rights and politics" (1995) 71(1) Indiana Law Journal 27 at 42.

${ }^{43}$ Id at $42-43$.

${ }^{44}$ M Mamdani "Peace, justice and ethnic conflict" (3 March 2014) CODESRIA Newsletter (Senegal)

${ }^{45}$ Ibid.

${ }^{46}$ Raz "Rights and politics", above at note 42 at 44.

${ }^{47}$ LJ Chimango "Tradition and traditional courts of Malawi" (1977) 10 Comparative and International Law Journal of Southern Africa 40.

${ }^{48}$ LawNigeria.Com "Nigeria" available at: < http://lawnigeria.com/Nigeria/Nigeria.html > (last accessed 12 September 2014)

${ }^{49}$ TK Adekunle "Nigerian indigenous courts and their dispute resolving mechanisms in global perspective", available at: <http://www.aija.org.au/NAJ\%202010/Papers/Adekunle\%20TK.pdf > (last accessed 5 September 2014) at1.
} 
Okoroafor Mbadiniju \& Ors v Chukwunere Ezuka, ${ }^{50}$ a land resource related conflict which was tried up till the Supreme Court of Nigeria. The suit was commenced in June 1977 when the plaintiffs of Umuezeawara Village in Anambra State of Nigeria claimed successfully at the high court that the defendants of an adjoining village were their customary tenants and that having denied their being over-lords, the plaintiffs were entitled to recover the land on which the defendants had lived with their ancestors from time immemorial. On the implication of the decision, Udechukwu recounts: "when the plaintiffs of Umuezeawara, Ihiala, Anambra State won at the Nnewi High Court, they proceeded to demonstrate their victory by planting crops in every open space within the defendant's homestead even on the village grounds and approach roads. ${ }^{, 51}$ The defendants appealed to the Court of Appeal which reversed the decision of the trial court. Reflecting on the reaction of parties to the judgement of court, Udechukwu recalls:

"The crops were in full bloom nearing harvest time when the High Court Judgment was reversed by the Court of Appeal Enugu, in a judgment which returned the case to the High Court for retrial before another Judge. Immediately following the Court of Appeal decision, the defendants destroyed all the crops planted by the plaintiffs without any trace." 52

Subsequently, on October 7, 1994, seventeen years after the commencement of the matter, the Supreme Court allowed the appeal and reinstated the judgement of the trial court. The sad consequence of this judgement was most unprecedented:

"This time, the victorious plaintiffs went to the entire village of the defendants with maniacal rage and vengeance, burning every building standing there, destroying every crop standing there and turning the place a desolate waste. Thereafter they set about partitioning the entire village to themselves. The defendants' village ceased to exist. This happened even though the two villages had intermarried for centuries. In fact the sister of the champion of the defendants was and is still married to the champion of the plaintiffs." 53

The fact that intervention is only possible when parties initiated actions in the courts and "the winners take all" approach of the judgment reveal the pathetic outcome of relying on courtroom litigation and decision for addressing resource related conflict. It hints that the reliance on the court alone as the bearer of constitutional duty to resolve claims in such conflict scenarios may not always help in achieving peaceful resolution.

\section{The limit of customary institutions as an 'essential' for resolving identity-based conflicts}

One may argue, not without merit, that the customary institutions (courts or otherwise) established under statutes or informally are different and more useful than the courts of records in addressing conflict situations. ${ }^{54}$ For instance,

\footnotetext{
${ }^{50}$ Okoroafor Mbadiniju and Ors v Chukwunere Ezuka [1994] LPELR-SC 232.

${ }^{51}$ Cited in K Aina "Keynote Speech" (paper delivered at the NIALS Intensive Course on Alternative Dispute Resolution, Nigeria, 13 August 2012) at 4-5.

${ }^{52}$ Id at 5 .

${ }^{53}$ Id at 6

${ }^{54}$ Adekunle "Nigerian indigenous courts", above at note 49 at 5.
} 
unlike courts of records, customary courts are presided over by lay men, ${ }^{55}$ and consequently follow simple procedures with little or no regard for legal technicalities. ${ }^{56}$ They derive their legal basis from laws including the constitution $^{57}$ and state edicts, ${ }^{58}$ and account for no less than $80 \%$ of the judicial work in every state of Nigeria which bear eloquent testimony to their significance in conflict management. ${ }^{59}$ Also, informal institutions are set up at different levels including clan and village levels where traditional rulers focus on amicable settlement of issues in what are often referred to as "palace courts" ${ }^{60}$ These channels utilise wisdom of the elderly as an important tool for fostering peaceful co-existence and management of conflicts. For instance, among the Yorubas, three hierarchies which include the elderly and palace courts in conflict prevention and resolution are evident. These are namely the baale ${ }^{61}$ the mogaji, ${ }^{62}$ and the olubadan ${ }^{63}$ in Council. According to Albert, Awe, He'rault and Omitogun, in Ibadan, the mogaji is formally recognized as the head of an $e b i,{ }^{64}$ by the hierarchical power structure. The mogaji is usually the eldest or most influential person in the ebi. A baale is deemed responsible where his opinions and decisions are respected by those within his household. ${ }^{65}$ According to the findings of Fadipe, the baale is also a mediator whose thoughts in disputes among members of his family are usually respected. Where disputes cannot be resolved or decisions reached, such matters may be referred to the mogaji or in unusual cases to olubadan in council. ${ }^{66}$

Both the informal and court based customary institutions apply customary laws which are community owned, flexible, dynamic and can adapt to conflict scenarios and achieve amicable resolution of matters. These essential features of customary law and institutions were given judicial recognition in Oyewunmi Ajagungbade III $v$ Ogunsesan which described customary law as "the organic or living law of an indigenous people of Nigeria regulating their lives and transactions." ${ }^{67}$ The features were also restated in Agbai v Okogbue ${ }^{68}$ where the Supreme Court of Nigeria held that "customary laws were formulated from time immemorial. As our society advances, they are more removed from its pristine social ecology. They meet situations which were inconceivable at the time they took root. ${ }^{, 69}$ Therefore, customary laws and institutions are an important means of conflict resolution and

${ }^{55}$ LawNigeria.Com "Nigeria" available at: < http://lawnigeria.com/Nigeria/Nigeria.html $>$ (last accessed 12 September 2014).

${ }^{56}$ AA Oba "Neither fish nor fowl: Area courts in the Ilorin emirate in Northern Nigeria" (2009) Journal of Legal Pluralism 69 at 70.

${ }^{57}$ Nigerian 1999 Constitution, sec 19.

${ }^{58}$ An example of such Laws is Customary Law (Cap 41) Laws of Oyo State, 2002.

${ }^{59}$ TK Adekunle "Customary courts in Nigeria: The neglected cornerstone in the dispensation of justice" in MAD Bello, NM Jamo and AM Madaki (eds) Administration of Justice in the Customary Courts of Nigeria: Problems and Prospects (2009, Private Law Department of Ahmadu Bello University) at 345-346.

${ }^{60}$ Emelonye and Chukwumaeze "Constitutional development", above at note 34 at 7.

${ }^{61}$ The Baale means household head.

${ }^{62}$ The Mogaji means the head of the extended family.

${ }^{63}$ The Olubadan is the title of Ibadan king.

${ }^{64}$ The Ebi means extended family.

${ }^{65}$ IO Albert, T Awe, G Herault and W Omitogun Informal Channels for Conflict Resolution in Ibadan, Nigeria (1995, IFRA) at 9-10.

${ }^{66}$ NA Fadipe Sociology of the Yoruba (1970, Ibadan University Press) at 106.

${ }^{67}$ Oyewunmi Ajagungbade III \& Anor v Amos Owoade Ogunesan [1990] SC 26/1988 at 73. See also, D Nareboh Customary Courts: Their Relevance Today (1993, Jodah) at 31.

${ }^{68}$ Agbai v Okogbue [1991] 7 NWLR (Pt. 204) 391.

${ }^{69}$ Id at 417. 
management. ${ }^{70}$ In addition to embodying the moral code or communitarian ethics, in aiming at reconciliation and harmony, customary laws and institutions contribute to the integration of the society. ${ }^{71}$

Even though the process is non-technical and adversarial, the relevance of customary law and institutions for solving violent conflicts linked to identity is limited in terms of certain aspects of their process and outcome. First, in relation to the application of customary law through informal channels such as the palace courts, official intervention and manipulation are not ruled out as a result of dependence on the state for income. ${ }^{72}$ Also, since it is usually removed from any official accountability, the role of traditional rulers in such mechanism can be subject to dictatorship and corruption. ${ }^{73}$ Largely dominated by the male, it remains patriarchal with the result that the voices of women are either unheard or altogether excluded in the dispute settlement framework in traditional settings. ${ }^{74}$ Second, the dispute management strategies often generated by such institutions are localized and cannot be generalized beyond local boundaries. In relation to interventions by traditional institutions, Osaghe argues, where located in ethnic groups, they may be seen as a continuation of ethnic domination by one ethnic group of another and further exacerbate conflicts. ${ }^{75}$

Third, generally, the application of customary laws presupposes parties who share similar customs, a feature which may not apply in the case of ethnicity or religion based conflicts where parties may not share similar customary values let alone laws. This signifies that if applied to conflicts associated with identity, there is a risk that a people involved in identity based violent conflicts may be held liable by a custom they do not adhere to. Hence, the likelihood that different customary law may be personal to different participants in violent conflict situations is a disincentive for relying on customary laws and institutions. Finally, even in communities with known customary laws, the possibility cannot be ruled out that what is projected and applied as customary laws is not the living customary law but the official version which may do more harm than good. Scholars including Bennet distinguish "official customary law" from "living customary law". The former, largely traced to the advent of colonialism, refers to rules imposed by external authorities without local support and lacks legitimacy while the latter is not fixed in any written codes and is dynamic. ${ }^{76}$ In terms of outcome, the application of the former, indeed, may operate as a potential source of conflict escalation.

In all, the foregoing arguments illustrating the weaknesses of courts and customary institutions in terms of their process and outcome undermine the reliance on these infrastructures as the sole institutional essential for conflict management and justify the need for an alternative conflict management mechanism as a complement. This

\footnotetext{
${ }^{70}$ Adekunle "Nigerian indigenous courts", above at note 49 at 19.

${ }^{71}$ N Funk "Localizing Peace: An agenda for sustainable peacebuilding" (2010) 17 (1) Peace and Conflicts Studies 101 at 116 . See also CRM Dlamini "The role of customary law in meeting social needs" in TW Bennet, DJ Devine, DB Hutchison, I Leeman, CM Murray and DZ Smit (eds) African Customary Law (1991, Juta \& Co, Ltd) 71, at 72 and 84.

${ }^{72}$ KB Motshabi and SG Volks "Towards democratic chieftaincy principles and procedures" in TW Bennet, DJ Devine, DB Hutchison, I Leeman, CM Murray and DZ Smit (eds) African Customary Law (1991, Juta \& Co, Ltd) 104 at 108. See also K Wiredu Philosophy and an African Culture (1980, Cambridge University Press) at 2-5.

${ }^{73}$ Ibid.

${ }^{74}$ TW Bennet Human Rights and African Customary Law (1995, JUTA) at 85. See also EE Osaghae "Applying traditional methods to modern conflict: Possibilities and limits" in IW Zartman (ed) Traditional Cures for Modern Conflicts: African Conflict Medicine (2000, Lynne Rienner Publishers) 201 at 214-215.

75 Ibid.

${ }^{76}$ T Bennet "Official' vs 'living' customary law: Dilemmas of description and recognition" in A Claassens and B Cousins (eds) Land, Power and Custom: Controversies generated by South Africa's Communal Land Rights (2009, UCT Press) 138 at 144-145. See also Dlamini "The role of customary law in meeting social needs", above at note 71 at 72 .
}

Page $\mathbf{8}$ of $\mathbf{2 0}$ 
conclusion agrees with the notion of constitutional "essential" in that the concept does not totally exclude an alternative mechanism of conflict management. For instance, Raz admits that apart from the role of courts and parliaments which dominate discussion on the appropriate forum for rights protection, there are "more channels of political action" ${ }^{77}$ Similarly, while stressing the role of courts in accountability over social rights, King explains the management of public law disputes through mediation, particularly, its encouragement by Lord Woolf "in both judicial and extra judicial capacity". ${ }^{78}$ The author then concludes that mechanisms promoting dispute resolution other than the courts are institutional "partners" in safeguarding constitutional aspirations and motivating social change. ${ }^{79}$ Particularly, in resolving political disputes, Chukwuemerie views that the courts can be complemented through the use of alternative dispute resolution. ${ }^{80}$ This suggests that an alternative conflict management tool can be useful in reconciling parties on conflicting issues of rights and governance. It signifies that the construction of constitutional essential as embodying a vision of an alternative conflict management mechanism can be validly made.

However, the 1999 Constitution of Nigeria only projects the courts as the sole "essential" institution in addressing conflict situations in matters of rights and governance. ${ }^{81}$ This is not adequate for resolving identity related conflicts confronting the nation. It has been argued that the making of a constitution is always an open and incomplete project, ${ }^{82}$ and its content, a learning process amenable to review and change in the light of new experiences. ${ }^{83}$ In the light of the foregoing, the next issue that merits discussion is the grounds on which the case for an alternative conflict management mechanism such as "a panel of the wise" can be made for inclusion in the Nigerian constitution.

\section{JUSTIFYING A PANEL OF THE WISE AS A CONSTITUTIONAL ESSENTIAL}

\section{Plurality of the Nigerian state and the search for peace}

The overarching goal for creating what is known as modern Nigeria is purely administrative and economic. ${ }^{84}$ In consequence, what constitutes the Nigerian state is a plural society divided by such identities as ethnicity, religion, language, and natural resource. ${ }^{85}$ Regarding ethnic plurality, experts estimate that Nigeria contains between 250 and 400 distinct ethnic groups including three major players: the Yoruba, Hausa and Ibo. ${ }^{86}$ Since its independence, a national identity has been difficult to achieve, the failure of which has created space for identification along the line

\footnotetext{
${ }^{77}$ Raz "Rights and politics", above at note 42.

${ }^{78}$ J King Judging Social Rights (2012, Cambridge University Press) at 94.

${ }^{79}$ Id at 85-93.

${ }^{80}$ A Chukwuemerie "Necessity as the mother of trial blazing: Applying alternative dispute resolution mechanisms to political party disputes in Africa" (2009) 2(4) Journal of Politics and Law 121 at 132.

${ }^{81}$ Id chap 7 generally describes the power of courts.

${ }^{82}$ C Cronin "On the possibility of a democratic constitutional founding: Habermas and Michelman in dialogue" (2006) 19 Ratio Juris 343 at 356.

${ }^{83}$ J Habermas "Struggles for recognition in the democratic constitutional state" in A Gutman (ed) Multiculturalism (1994, Princeton University Press) 107 at 135.

${ }^{84}$ CBN Ogbogbo "Nigeria-Niger Delta relations 1960 - 1995" in O Akinwumi, OO Okpeh Jr. and JD Gwamna JD (eds) Inter-group relations in Nigeria in the 19th and 20th Centuries (2006, Aboki publishers) 550 at 553.

${ }^{85}$ AA Oba "Religious and customary laws in Nigeria" (2011) 25 Emory International Law Review 881 at 882.

${ }^{86}$ Akpan "Governance and communal conflicts in a post-democratic Nigeria", above at note 16 at 65.
} 
of religion, ethnicity and resources to assume wider importance. ${ }^{87}$ This was worsened by the repression under military regimes which punctuated democratic governance in Nigeria and largely, in Davidson's view, behaved 'like pirates in power. ${ }^{88}$ The manipulation of identities remains the very foundation on which democracy project is anchored in Nigeria, ${ }^{89}$ and has remained so since 1999 when Nigeria returned to democracy.

Reflecting the trend in this regard are conflicts in the Niger Delta which are largely due to the inability of the multinational companies involved in the explorations and exploitation of crude oil, and the federal government to adequately mitigate the consequences of their activities in the region. ${ }^{90}$ Conflicts around religion, "indigene" rights and political representation in Jos have become protracted affecting most parts of the state, raising wider security issue in Nigeria. ${ }^{91}$ As many as 7,000 peoples have been killed since late 2001, when the first major riot broke out. ${ }^{92}$ Similarly smacking of religion is the conflict between federal government of Nigeria and Boko Haram which has claimed thousands of lives. ${ }^{93}$ Beginning as a minor skirmish in Yobe State, the Boko Haram conflict has escalated with several death tolls including the leader of the movement, Mohammed Yusuf, in 2009. ${ }^{94}$ The spate of attacks by Boko Haram changed since 2010 as illustrated in the UN office bombing, attempted bombing of the Nigeria Police Headquarters and coordinated attacks in Damaturu, Maiduguri and Kano. ${ }^{95}$ The consequence of the foregoing is that, thus far, Nigeria is yet to experience the much discussed correlation between democratic governance and peace. ${ }^{96}$

There is merit in blaming the above scenarios partly on the organic instrument, that is, the constitution, on which basis the nation is being governed. In particular, in failing to provide a mechanism to foster peace and assist with non-partisan and adversarial intervention in issues of ethnic, religious, resource based violent conflicts, there is gap in the constitutional conception of Nigeria as a plural state. A proper appreciation of the plural nature of Nigeria would have allowed for a mechanism which focuses on non-adversarial management of identity related conflicts as enshrined in national constitutions of some African states.

\section{The trend in national constitutions}

A role for a body or tool focusing on non-adversarial conflict management that can inform the creation of "a panel of the wise" has found expression as an "essential" in the constitutions of some states in Africa, including such states with a history of identity related violent conflicts. Article 61 of the 1995 Constitution of the Federal Republic of Ethiopia, for instance, establishes the House of the Federation, composed of representatives of nations, nationalities and peoples. One significant function of the house is to strive to find solutions to disputes or

\footnotetext{
${ }^{87}$ O Adeyeri "Federalism and the challenges of nation-building in Nigeria" (2010) 2 International Journal of Research in Arts and Social Sciences 24.

${ }^{88}$ Quoted in Maier This House Has Fallen, above at note 20 at xx.

${ }^{89}$ Mijah Democracy, Internal Security and the Challenges of Policing in Nigeria, above at note 28 at 3-7.

${ }^{90}$ Akpan "Governance and communal conflicts in a post-democratic Nigeria", above at note 16 at 66-67.

${ }^{91}$ Osareti and Akov "Ethno-religious conflict and peace building in Nigeria", above at note 24.

${ }_{92}^{92}$ J Krause "A deadly cycle: ethno-religious conflict in Jos, Plateau State, Nigeria” (Working paper, Geneva, 11 June 2011 ) at 9.

${ }^{93}$ JJF Forest Confronting the Terrorism of Boko Haram in Nigeria (2012, JSOU Print) 12-15.

${ }^{94}$ Ibid.

${ }^{95}$ T Johnson "Boko Haram", available at: 〈http://www.cfr.org/africa/boko-haram/p25739> (last accessed 8 September 2012).

${ }^{96}$ M McFaul Advancing Democracy Abroad: Why we should and How we can (2009, Rowman and Littlefield) at 14. See also J Siegle, MM Weinstein and MH Halperin "Why democracies excel" (2004) 83(5) Foreign Affairs 57-72, arguing that democracies enhance political stability.
} 
misunderstandings that may arise between different components of the state. ${ }^{97}$ Other constitutional role of the House includes conflict management. ${ }^{98}$ The house has played significant role in addressing conflicts relating to ethnicity, ${ }^{99}$ resource allocation and power distribution, ${ }^{100}$ using means including referendum in areas of Oromia and Somali regions to assess public opinion. Particularly, it supervised referenda on disputes between some kebeles in the Shinele zone of the border area between Oromia and Somali States. ${ }^{101}$ In Burundi, the Post-Transition Interim Constitution provides for the National Council of Bashingantahe whose responsibilities include giving advice on essential questions concerning unity, peace and national reconciliation. ${ }^{102}$ The Bashingantahe which includes men and women of integrity, wisdom and love plays a crucial role in traditional society as drivers of social cohesion and resolver of "non-judicial conflicts". ${ }^{103}$ Particularly in the 1993 ethnic cleansing crisis, they intervened to save a lot of lives. ${ }^{104}$ Also, the new Kenya Constitution empowers the parliament to make law which encourages the application of traditional dispute resolution mechanisms for managing conflicts related to land. ${ }^{105}$

Even in the legal systems where plurality of identity is not a recurring source of tension and violence, there exists a role for a group focusing on non-adversarial resolution of conflicts. In the Kingdom of Swaziland, the Tindvuna is a constitutional body of headmen which assists in the traditional governance of the country in areas including the hearing of complaints and advising on the tempo of the nation. ${ }^{106}$ The constitution of the self declared state of Somaliland establishes the House of Elders and vests it with the power to address issues regarding the security and peace of the country. ${ }^{107}$ While it is not a constitutional creation, the National Peace Council (NPC) was established in Ghana by a cabinet decision in 2007 and by the parliament as an autonomous national statutory commission in May 2011 by virtue of NPC Act of $2011 .^{108}$ The NPC is of the mandate to prevent, manage, and resolve conflict in Ghana. Its membership was drawn from academia, religious groups, traditional leaders and the business community, ${ }^{109}$ and performs noticeable role. For instance, the Bawku conflict, a matter fought up to supreme courts without an end to crisis, ${ }^{110}$ is a deep seated and longstanding ethno-political conflicts between two ethnic groups- the Kusasis and Mamprusis in the Bawku Traditional Area of Ghana. ${ }^{111}$ In that conflict situation, the Council intervened, drew up a roadmap to peace, ${ }^{112}$ and embarked on peace education for various ethnic groups, on

\footnotetext{
97 The 1995 Constitution of the Federal Republic of Ethiopia, art 62 (6).

${ }^{98}$ AF Weldemariam "Conflict management in the Ethiopian multi-national federation" (unpublished dissertation, the European University Center for Peace Studies, Stadtschlaining, Austria, February 2009) at 65.

${ }^{99}$ Id at 53.

${ }^{100}$ A Kefale "Federalism: Some trends of ethnic conflicts and their management in Ethiopia" in AG Nhema (ed) The Quest for Peace in Africa: Transformations, Democracy, and Public Policy (2004, International Books) 51 at 60 and 67.

${ }^{101}$ Weldemariam "Conflict management in the Ethiopian multi-national federation" above at note 98 at 67.

102 The 2004 Post-Transition Interim Constitution of the Republic of Burundi, art 269.

103 A Naniwe-Kaburahe "The institution of Bashingantahe in Burundi" in International Institute for Democracy and Electoral Assistance (ed) Traditional Justice and Reconciliation after Violent Conflict: Learning from African Experiences (2008, International Institute for Democracy and Electoral Assistance) 149 at 154 and 174.

${ }^{104}$ Id at 153.

105 The Constitution of Kenya, 2010, art 67(2)(f).

106 The 2005 Constitution of the Kingdom of Swaziland, sec 235 (4).

107 The 2001 Constitution of Somaliland, art 57.

${ }^{108}$ Available at <www.mint.gov.gh/dmdocuments/a_peace_architecture_for_ghana_pdf.> (last accessed 5 September 2014).

${ }^{109}$ Ghana News Agency: "President Mills inaugurates newly constituted National Peace Council" (11 November 2011, Ghana News Agency), available at: <http://www.ghananewsagency.org/politics/president-mills-inaugurates-national-peace-council-board-35465> (last accessed 5 September 2014).

${ }^{110}$ BK Noagah "The peace process in the Bakwu conflict in Ghana: Challenges and prospects" (2013) 12(2) Conflict \& Communication 1 at 2.

${ }^{111}$ Ibid.

${ }^{112}$ Ibid.
} 
the ways the conflict can be resolved. ${ }^{113}$ Generally, it plays significant role in supporting district and regional security Councils on conflict prevention, conflict management and resolution. ${ }^{114}$ Nevertheless, the general practice in some national constitutions is not the only basis for urging the creation of a "panel of the wise" as essential for the Nigerian constitution. There is a trend in the regional and sub-regional instruments evidencing that the creation of the proposed panel is visible.

\section{The trend in regional and sub-regional instruments}

Regional and sub-regional instruments are an important example on the establishment of a panel of the wise or similar mechanism as a conflict and peace intervention mechanism. Their provisions in relation to composition and functions of such mechanisms are an important precedent to guide the inclusion of a panel of the wise as an essential content of the Nigerian constitution. In tracing the meaning of a "panel of the wise" as it is understood in a contemporary legal instrument, the reference point both for its composition and role is the AU Protocol Relating to the establishment of the Peace and Security Council, ${ }^{115}$ a pillar instrument on peace and security in Africa. ${ }^{116}$ According to the Protocol, members of the panel are composed of "highly respected African personalities" who have made significant contribution to the "cause of peace, security and development" in Africa. ${ }^{117}$ The five member panel are individuals who are deemed non-participant and are selected based on regional representation and serves for a period of three years. ${ }^{118}$ Similar to the first appointment made in $2007,{ }^{119}$ the emphasis on non-partisanship, trackrecord and gender balance for the membership of the panel is reflected in the appointment of five new members at the 23rd Ordinary Summit, held in Malabo, Equatorial Guinea, on 26 and 27 June 2014. ${ }^{120}$ The appointed members are Dr Lakhdar Brahimi, a former special envoy and foreign minister from Algeria (North Africa), ${ }^{121}$ and Mr Edem Kodjo, former minister of finance and foreign minister from Togo (West Africa). ${ }^{122}$ As a mark of commitment to gender balance, Dr Albina Faria de Assis Pereira Africano, former minister of petroleum and industry from Angola (Central Africa); Dr Luisa Diogo, former minister of finance from Mozambique (Southern Africa) and Dr Specioza Naigaga Wandira Kazibwe, former minister of gender and community development, from Uganda (East Africa) are female members of the panel. ${ }^{123}$

\footnotetext{
113 Id at 7.

114 Ghana News Agency: "National Peace Council deploys Staff to regions" (13 November 2013, Ghana News Agency), available at: <http://www.ghananewsagency.org/social/national-peace-council-deploys-staff-to-regions--67151> (last accessed 5 September 2014).

115 AU Protocol Establishing the Peace and Security Council, art 3. See also Solemn Declaration on a Common African Defence and Security Policy (CADSP), Second Extraordinary Session, in Sirte, Great Libyan Arab Jamahiriya, on 28 February, 2004.

${ }^{116}$ Other pillars are the Continental Early Warning System, Peace Fund, the African Standby Force (ASF) and African Common Defence Policy, see A Vines "A decade of African peace and security architecture" (2013) 89 (1) International Affairs 89 at 90. See also J Sarkin "The role of the United Nations, the African Union and Africa's Sub-Regional Organizations in dealing with Africa's human rights problems: Connecting humanitarian intervention and the responsibility to protect" (2009) 53(1) Journal of African Law 1 at 16.

${ }_{117}$ AU Protocol Establishing the Peace and Security Council, art 11(2).

${ }^{118}$ Ibid. See also AO Jegede "The African Union peace and security architecture: Can the panel of the wise make a difference?" (2009) 9 (2) African Human Rights Law Journal 409 at 417.

${ }_{119}$ African Union Assembly "Decision on the appointment of the members of the panel of the wise" Assembly/AU /Dec.152.152(VIII)

${ }^{120}$ African Union press release: "The Chairperson of the AU Commission looks forward to working closely with the new AU panel of the wise" (9 July 2014, African Union).

${ }^{121}$ Ibid.

122 Ibid.

${ }^{123}$ Ibid.
} 
The panel is established to assist the Peace and Security Council and the Chairperson of the Commission in their efforts, especially, in the area of conflict prevention. ${ }^{124}$ It adopted its Modalities on 12 November 2007, ${ }^{125}$ which, in clearer details, sets out its functions. Mainly, the panel offers recommendation on issues relating to the advancement and maintenance of peace, security and stability in Africa. ${ }^{126}$ When necessary and, in any form it deems applicable, the panel can pronounce itself on any issue relating to the promotion and maintenance of peace, security and stability in Africa. ${ }^{127}$ It can carry out this task either at the request of the Council or the Chairperson of the Commission, or at its own initiative. ${ }^{128}$ It can receive, for inclusion in its agenda, proposals from any member of the panel, the Council, the Chairperson of the Commission, the Pan-African Parliament, the African Commission on Human and People's Rights and civil society groups. ${ }^{129}$ The panel uses fact-finding missions, good-offices missions, and supporting mediation initiatives as part of its tools of intervention. ${ }^{130}$

In formulating general functions of the panel, the protocol does not expressly refer to identity based violent conflicts. Arguably, conflicts of such nature are not unrelated to its functions. Identity based conflicts can be linked to the working of the panel by virtue of the Solemn Declaration on a Common Africa Defence \& Security Policy (CADSP), an instrument established pursuant to article 7 of the AU PSC Protocol, which confers on the PSC the power to implement the CADSP. ${ }^{131}$ The CADSP requires the establishment of political organizations devoid of sectarian, religious ethnic, regional and racial extremism. ${ }^{132}$ As discernible from article 14(g) of the CADSP, the intention of the declaration is to combat racism, religious extremism and xenophobic tendencies, encourage national identity, ${ }^{133}$ and external and internal interests in exploitation of resources. ${ }^{134}$ Consequently, since the overall role of the panel of the wise is to assist the PSC and Chairman of the Commission whose tasks include the implementation of CADSP, it can be validly argued that the functions of the panel include the assistance with the prevention and resolution of violent conflicts linked with identities.

Although criticized for its failure to do anything significant in the case of Mali and CAR, ${ }^{135}$ and imperfect in the sense that it faces challenges including inadequate resources, visibility and accessibility, ${ }^{136}$ the panel has engaged with identity related issues in violent conflict situations, at least, in the context of electoral violence. In a report, it noted that "elections provide opportunity to express other grievances about resource sharing and ethnic

\footnotetext{
${ }^{124}$ AU Protocol Establishing the Peace and Security Council, art 11 (1).

${ }^{125}$ Modalities for the functioning of the panel of the wise, adopted by the Peace and Security Council at its 100th Meeting held on 12 November 2007.

${ }^{126} \mathrm{Id}, \sec \mathrm{II}(1)$.

${ }^{127} \mathrm{Id}, \sec \mathrm{II}(3)$.

${ }^{128} \mathrm{Id}, \sec \mathrm{II}(4)$.

${ }^{129} \mathrm{Id}, \sec \mathrm{IV}(8)$.

${ }^{130}$ Modalities for the functioning of the panel of the wise, sec III (1) (a)-(h) and (2).

${ }^{131}$ AU Protocol Establishing the Peace and Security Council, art 3. See also Solemn Declaration on a Common African Defence and Security Policy (CADSP), Second Extraordinary Session, in Sirte, Great Libyan Arab Jamahiriya, on 28 February, 2004, introduction, para 3.

${ }^{132}$ CADSP, para 11.

${ }^{133}$ CADSP, para $14 \mathrm{~h}$.

${ }^{134}$ CADSP, para $14 \mathrm{j}$.

${ }^{135}$ MT Maru “A decade later: Is the African Union still relevant?"(26 January 2014), available at:

<http://www.aljazeera.com/indepth/opinion/2014/01/au-summit-too-little-too-late-201412164643828344.html> (last accessed 4 September 2014).

${ }^{136}$ AO Jegede "Beyond prospects: Strengthening the panel of the wise in the AU Peace and Security Architecture" (2012) 1(1) Journal of African Union Studies 67 at 77.
} 
rivalry". ${ }^{137}$ It observes that elections have aggravated communal, ethnic and religious conflicts in Africa, ${ }^{138}$ taking the forms of ethnic cleansing, balkanization, sabotage, evictions, and mass displacements. ${ }^{139}$ It notes that the uprisings, social unrest in North Africa of 2011, are linked with issues such as ethnicity, religious marginalisation and gender imbalances. ${ }^{140}$ Generally, the panel has shown its willingness to mediate issues which may fuel identity based violence. It engaged with several political crises, including those in Guinea, Guinea-Bissau, Madagascar, and Zimbabwe. ${ }^{141}$ The panel carried out a mission to the Democratic Republic of Congo (DRC) from 6 to 8 October $2011,{ }^{142}$ and has been active in mediating conflict in Mali, Ivory Coast, Libya and Egypt. ${ }^{143}$

Sub-regional bodies such as the Economic Community of West African States (ECOWAS) and the Southern African Development Community (SADC) have also developed institution and practices similar to the panel of the wise. Article 20 of the Protocol Relating to the Mechanism for Conflict Prevention, Management, Resolution, Peace-keeping and Security of ECOWAS (ECOWAS Protocol) creates the Council of Elders. Under the ECOWAS arrangement, the Executive Secretary is required to annually compile a list of eminent persons from various segments of society, including women, political, traditional and religious leaders. These are persons who, on behalf of ECOWAS, can use their good offices and experience to play the role of mediators, conciliators and facilitators whenever conflicts arise. The Council of Elders is constituted from an approved list to deal with specific conflict situations. ${ }^{144}$ This Council of eminent personalities, on behalf of ECOWAS, can use their good offices and experience to address issues capable of breaching peace and security within the region. The Council has been engaged in handling the crisis arising from the proliferation of small arms in the sub-region. ${ }^{145}$ The council's activities include election observation, monitoring of human rights abuses, supporting peace processes, providing counselling to heads of state and government and to ECOWAS, undertaking "quiet diplomacy", which is devoid of publicity. ${ }^{146}$

Although the SADC Protocol on Politics, Defence, and Security Cooperation does not provide for a similar Council, article 11 (3)(a) of SADC Protocol mandates the Organ on Politics, Defence, and Security Cooperation to prevent, manage and resolve conflict by peaceful means. To this end, eminent persons are engaged by SADC as shown in the example of Lesotho and Madagascar where they were involved in post- election political concerns. ${ }^{147}$

\footnotetext{
${ }^{137}$ Election-related disputes and political violence: Strengthening the role of the African Union in preventing, managing, and resolving conflict: Report of the AU panel of the wise (July 2010, African Union).

138 Id at 22-23.

139 Id at 23 .

${ }^{140}$ Id at 24

${ }^{141}$ PD Williams “The African Union's conflict management capabilities" (October 2011), available at:

<file://C:/Users/User/Downloads/IIGG_WorkingPaper7.pdf> (last accessed 4 September 2014) at 13. See also African Union press release: POW/PR/COMM(XII) "12th meeting of the panel of the wise of the African Union" (30 April 2012, African Union)

${ }^{142}$ Report of the Chairperson on the activities of the Commission covering the period July to December 2011: EX. CL/688(XX) (Twentieth Ordinary Session of the AU Executive Council, Addis Ababa, Ethiopia, 23 - 27 January 2012) at para 120.

143 P Kagwanja "Issue briefs series", available at: <http://www.ipstc.org/media/documents/ISSUE\%20BRIEF\%20No5_Q3-2013> (last accessed 4 September 2014) at 14.

${ }^{144}$ Protocol Relating to the Mechanism for Conflict Prevention, Management, Resolution, Peace-keeping and Security, done at Lome, 10 December, 1999, art 20.

${ }^{145}$ Jegede "The African Union peace and security architecture", above at note 118 at 415.

${ }^{146}$ The African Union Panel of the Wise: Strengthening relations with similar Regional Mechanisms: Report Based on the High Level Retreat of the African Union Panel of the Wise (4 and 5 June 2012, Burkina Faso) at 36.

${ }^{147}$ Communiqué of the 29th Summit of SADC Heads of State and Government, at para 6, available at: <http://www.dirco.gov.za/docs/2009/sadc0910.html> (last accessed 6 September 2014).
} 
The approach in relation to appointment as SADC eminent persons is one of case by case basis. ${ }^{148}$ For instance, while Sir Ketumile Masire, former President of the Republic of Botswana was appointed as the eminent person and mediator for Lesotho, Joaquim Alberto Chissano, former President of the Republic of Mozambique, was the appointed eminent person and mediator for Madagascar respectively. ${ }^{149}$ Along similar lines, the Common Market for Eastern and Southern Africa (COMESA) Committee of Elders was established during the ninth meeting of the COMESA Ministers of Foreign Affairs, to address conflict trends among and within its member states. The committee's mandate is to steer the course of preventive diplomacy for conflict resolution and augment COMESA's peacebuilding and peacemaking processes. ${ }^{150}$ Composed of five members, the COMESA Committee of Elders is similar with the AU panel of the wise. ${ }^{151}$ So far, the activities of the Committee of Elders have included election observation missions to the DRC, Uganda and Zambia. The committee also worked with the AU panel of the wise in undertaking pre-election assessment missions to the DRC and Egypt. ${ }^{152}$ Although the workings of these institutions are primarily in the context of election and electoral violence, it is difficult to imagine that violence and grievances bothering on identities such as religion, ethnicity, and indigene/settler are exempted from their attention.

What emerges from the foregoing discussions is that there is evident practice and precedent under national constitutions as well as regional and sub-regional instruments that can inspire, shape or be adapted in establishing and operationalizing a panel of the wise in Nigeria. The next section explores how these developments may shape certain considerations in terms of the composition, functions and legal status of intervention in establishing the proposed panel.

\section{ESTABLISHING A PROPOSED PANEL OF THE WISE: KEY CONSIDERATIONS}

\section{Composition of the panel}

As discussed in the above section, from existing examples on the composition of the panel of the wise, three options are available. ${ }^{153}$ The AU panel of the wise and the COMESA Committee of Elders have a statutorily prescribed membership of five, ${ }^{154}$ and are therefore limited in composition. This approach is different from ECOWAS which allows for a pool of the wise, composed of personalities from different regions of Africa and SADC approach which is based on appointment on case by case basis. In terms of the composition for Nigeria, arguably the approach by AU and COMESA which allows for a limited composition with membership spread across geo-political zones and due regard for gender can be adapted, at least, for two reasons. First, being a novel concept, limiting composition to a particular number increases the possibility of taking the mechanism seriously: it suggests that the threshold for

\footnotetext{
${ }^{148}$ Communiqué of the 29th Summit of SADC Heads of State and Government, at para 6.

${ }^{149}$ Ibid.

${ }^{150}$ COMESA Activities: "Peace and Security - Decision making organ", available at:

<http://programmes.comesa.int/index.php?option=com_content\&view=article\&id=96\&Itemid=114\&limitstart=2> (last accessed 6 September 2014).

${ }^{151} \mathrm{Id}$, para III.

${ }^{152}$ Report Based on the High Level Retreat of the African Union Panel of the Wise, above at note 146 at 35.

${ }^{153}$ Communiqué of the 29th Summit of SADC Heads of State and Government, at para 6.

154 See respectively, AU Protocol Establishing the Peace and Security Council, art 11(2) and COMESA Activities: "Peace and Security Decision making organ", above at note 150 at para III.
} 
selection is high and the profile of members is above board. Second, a limited composition brings within closer scrutiny and increases the confidence of the public in the panel more than a pool of wise whose membership may be unknown and beyond scrutiny. Finally, a limited composition is not problematic as, in any case, the proposed panel will be supported by a secretariat.

Accordingly, the constitution of Nigeria in establishing the panel may provide for a membership of six eminent personalities in line with the six geo-political zones in Nigeria as recognised in the constitution, ${ }^{155}$ with due regard for religion and gender balance. In addition to the emphasis on "distinction" and "track record" which are requirements generally discernible from national jurisdictions as with the NPC in Ghana and the Bashingantahe in Burundi as well as regional and sub-regional practices, the non-partisanship of the panellists can be ensured by involving the executive, legislature and civil society in the process of composition and removal of membership. For instance, the appointment or removal of a person as a panel member may be made by the President on the nomination of the members of the civil society subject to confirmation of such appointment by the Senate. The involvement of the civil society means the exclusion of the state from the empanelling and removal of a personality as a member of the proposed panel, a peculiar approach distinct from how political appointees are made. This approach can substantially reduce the influence of political pressure on the functioning of the panel. Further, the security of their office can be strengthened by making their tenure of office a renewable term of five years which is above the "magic" four year term for political office holders in Nigeria. ${ }^{156}$ This means, all things being equal, that members of the panel will outlive political office holders.

\section{Functions}

The proposed panel may intervene in identity based conflicts on its own initiative or when invited by parties or requested to do so by a member of the civil society. Generally, the functions for the proposed are in the areas of conflict prevention and management, and fostering of peace.

\section{Conflict prevention and management}

There is consensus that conflict prevention refers to any attempt by third parties to prevent the outbreak of violent conflict or its recurrence (preventive diplomacy). ${ }^{157}$ This definition, in the opinion of Stewart, includes short-term intensive diplomacy to resolve disputes or manage crisis which extends to the period after the outbreak of violent conflicts (conflict management).

\footnotetext{
${ }^{155}$ For political purposes, Nigeria is divided into six geopolitical zones, namely, South South, South East, South West, North Central, North East and North West, see Federal Government of Nigeria "Nigeria's path to sustainable development through green economy: Country report to the rio+20 summit 2012", available at: <http://sustainabledevelopment.un.org/content/documents/1023nigerianationalreport.pdf (last accessed 6 September 2014) at 1.

${ }^{156}$ Subject to reappointment for one more term, tenure of the president of the federation and the governor of a state and lapses after four years of assumption of office, see art 135(2) and 180 (2) respectively. The Senate and House of Representatives is dissolved after four years, art 64(1).

${ }^{157}$ EJ Stewart "Capabilities or coherence? The evolution of European Union conflict prevention" 13(2) (2008) European Foreign Affairs Review 229.
} 
Since the Nigerian constitution embodies the aspirations of the state for peace and stability, ${ }^{158}$ entrusting the panel with a conflict prevention and management role is necessary and will help to realise the national aspiration on peace and stability. As a result of its bi-partisan nature, the proposed panel should be saddled with the responsibility of stepping into burning issues stemming from identity before they escalate into violence and armed conflicts. This is pertinent as conflict situations in Nigeria are not sudden. Rather, as it has been argued, their root causes are often traceable to historical injustices which were allowed to fester due to lack of effective attention by political elite. ${ }^{159}$ In relation to full blown violent conflicts, the panel functions should include facilitation of mediation efforts involving affected stakeholders. This may require third party intervention such as mediation. Creating such a role for the panel in the constitution will afford it the legitimacy to serve as first point of call to participants in conflict as well as a neutral go-between in conflicts involving government and any other organised groups.

Experience from the National Peace Council (NPC) of Ghana shows that a mechanism such as the panel of the wise, can be useful in preventing or tackling complex conflicts. Even before officially inaugurated, the NPC has been credited in preventing or containing conflicts during the 2008 elections and earned the reputations as credible non-partisan institution. ${ }^{160}$ The influence of the NPC has extended to the regional parts where the Regional Peace Advisory Councils (RPAC) have been able to identify and mediate local conflicts early and so contain their escalation. The RPAC has thus become important early warning mechanisms in Ghana. ${ }^{161}$

\section{Fostering peace}

Fostering a culture of peace in an identity based society is a huge, yet a surmountable challenge. In addressing this challenge, the importance of peace education as stressed in several official documents of United Nations organizations such as UNESCO in 1974, ${ }^{162} 1980,{ }^{163} 1994 / 95,{ }^{164} 1996,{ }^{165}$ and the United Nations General Assembly in1978, ${ }^{166} 1995,{ }^{167} 1996,{ }^{168} 1999,{ }^{169}$ and $2002^{170}$ is useful. The UN Declaration on Culture of Peace and its programme encourage member States to take actions for promoting a culture of peace at the national level as well as

\footnotetext{
${ }^{158}$ Nigerian 1999 Constitution, sec 15 (1).

${ }^{159}$ BV Ikejiaku "The relationship between poverty, conflict and development" (2009) 2(1) Journal of Sustainable Development 15 at 16 and 22.

${ }^{160}$ UNDP "Assessment of development results: Ghana" (2011, UNDP), available at: < file:///C:/Users/User/Downloads/ADR-Ghana.pdf> (last accessed 5 September 2014) at xii, 28 and 29.

161 Id at 29.

${ }^{162}$ UNESCO "Recommendation Concerning Education for International Understanding, Co-operation and Peace and Education Relating to Human Rights and Fundamental Freedoms”, adopted by the General Conference at its eighteenth session Paris, 19 November 1974, at para IV (7).

${ }^{163}$ UNESCO "World Congress on Disarmament Education: Final Document and Report" (UNESCO House, Paris, 9-13 June 1980) at para II(2).

${ }^{164}$ UNESCO "Declaration and Integrated Framework of Action on Education for Peace, Human Rights and Democracy", at para II (9).

${ }^{165}$ UNESCO "Declaration of Principles on Tolerance" adopted by the General Conference of UNESCO at its twenty-eighth session in Paris, on 16 November 1995, art 3(2).

${ }^{166}$ United Nations General Assembly "Final Document of the Tenth Special Session of the United Nations General Assembly (SSODI - Special Session on Disarmament I)" (A/S - 10/4 United Nations General Assembly, New York).

${ }^{167}$ United Nations General Assembly "International Decade for a Culture of Peace and Non-violence for the Children of the World (2001-2010)" ( Resolution 53/25 United Nations General Assembly, New York).

${ }^{168}$ United Nations General Assembly "Final Report on the United Nations Year for Tolerance" ( Resolution A/51/201 United Nations General Assembly, New York).

${ }^{169}$ United Nations General Assembly "Declaration and Programme of Action on a Culture of Peace"( Resolution A/53/243 United Nations General Assembly New York).

${ }^{170}$ United Nations General Assembly “United Nations Study on Disarmament and Non-proliferation Education”( Resolution A/57/124. United
} Nations General Assembly, New York). 
at the regional and international levels. ${ }^{171}$ Reinforcing the importance of peace to the well-being of people in Africa, the African Charter on Human and Peoples' Rights (African Charter) equally guarantees the right of individual to national and international peace. ${ }^{172}$

Although the Nigerian Constitution does not codify peace as a human right, it is state party to the African Charter which recognises the right to national and international peace. ${ }^{173}$ When the provision of the Charter is read along with its aspiration for peace and unity expressed in the constitution, there is basis to encourage peace education as critical for creating an atmosphere needed for meaningful governance. Hence, the responsibility for the promotion of peace can be anchored in the panel. Entrusting the panel with such constitutional role will provide or advance appropriate framework to encourage peace education as a means of building the culture of peace in Nigeria. An example of what this can achieve is again discernible from Ghana, where the NPC has embarked on series of workshops aimed at making youth become ambassadors of peace. ${ }^{174}$

\section{Legal status of intervention}

A crucial issue in establishing the proposed panel is the legal status of the outcome its conflict interventions vis-àvis the other institutions such as the court primarily dealing with conflict management. Unlike the binding nature of court decisions, but similar to non-binding legal status of recommendations of the AU panel of the wise, ${ }^{175}$ the outcome of the intervention of the proposed panel is recommendatory and not legally binding. This is to be expected considering that the proposed panel will engage in conflict management with the view of prevention or helping parties to expand options and reach consensus on solution to grievances. Despite its recommendatory role, there is nothing preventing the relationship between the proposed panel and the court from being mutually reinforcing. There is a precedent on such relationship. For instance, the modalities of AU panel of the wise allow it to receive proposal for intervention from such bodies such as the Pan-African Parliament, the African Commission on Human and Peoples' Rights, a quasi-judicial mechanism. ${ }^{176}$ Hence, the functions of the panel can include the interaction with the court when necessary. Such possibilities are already opening in the rules of courts in Nigeria, demonstrating that interdependence is possible, at least, in the areas of initiating intervention and enforcement of outcome. There are provisions in the Lagos High Court Civil Procedure Rules 2012 (2012 Rules) which support a potential synergy of the panel and the court in Lagos State. The 2012 Rules provide that court registry can screen a matter brought before it for alternative dispute resolution (ADR) and where appropriate refers, such matter to ADR institutions. ${ }^{177}$ As the tools of intervention of the Panel will include mediation for the purpose of reconciliation, it can be argued that the panel comes within the meaning of ADR institution under the 2012 Rules and, therefore, can receive matters

\footnotetext{
${ }^{171}$ UNESCO “A Declaration on a Culture of Peace” A/53/243 Fifty-Third Session Agenda Item 31.

172 The African Charter on Human and Peoples' Rights (African Charter), Adopted by the OAU in Nairobi, Kenya, on 27 June 1981 and entered into force on 21October 1986, art 23.

${ }^{173}$ Nigeria deposited an instrument of ratification to the charter on 22/07/1983, available: <http://www.achpr.org/instruments/achpr/ratification/> (last accessed 10 September 2014).

174 "National Peace Council deploys Staff to Regions" above note at 114.

${ }^{175}$ AU Protocol Establishing the Peace and Security Council, art 11(3).

${ }^{176}$ Modalities for the functioning of the panel of the wise, sec IV(8).

${ }^{177}$ High Court of Lagos State (Civil Procedure) Rules 2012, Order 25 2(1).
} 
referred to it under rules of court. Similarly, Order 16 Rule 1 Sub-rule 1 of the Court of Appeal Rules 2011 provides:

\begin{abstract}
"At any time before an appeal is set down for hearing, the court may in appropriate circumstances upon the request of any of the parties refer the appeal to the Court of Appeal Mediation Program (CAMP); provided that such appeal is of a purely civil nature and relates to liquidated money demand, matrimonial causes, child custody or of such other matter as may be mutually agreed by the parties". ${ }^{178}$
\end{abstract}

The Court of Appeal Rules also allow parties the freedom to resort to any "alternative dispute resolution mechanism as considered appropriate in the circumstance". ${ }^{179}$ This means that in deserving situations, disputants can engage the panel for resolution of disputes, even if initial complaints have been commenced through court proceedings.

Possibilities exist that even if the outcome of an intervention by the proposed panel is recommendatory, participants in its intervention may benefit from the enforcement procedures of the court where necessary. That the outcome of panel intervention can be enforced, at least in Lagos State, is discernible from Order 39, rule 4 (3) of the High Court of Lagos State Civil Procedure Rules which provides that "an Award made by an Arbitrator or a decision reached at the Multi-Door Courthouse may by leave of a Judge be enforced in the same manner as a judgment or order of Court". ${ }^{180}$ Considering the way this provision is couched, it may be argued that the express mention of an "arbitrator" and "Multi-Door Courthouse" exempts from the wordings of the provision, the outcome of the panel's intervention. ${ }^{181}$ However, Order 39 rule 4(3) cannot be read in isolation of the general vision of the rules of court, which according to the preamble dealing with overriding objectives, is to encourage amicable resolution by use of ADR mechanism. Hence, read together with the overriding objective, being an alternative conflict management mechanism, the intervention of the panel is not excluded from the enforcement possibility of Order 39 rule 4(3). Similarly, upon the successful outcome of the engagement of an ADR mechanism, the Court of Appeal Rules allow the Court to adopt the agreement reached by parties as its judgement. ${ }^{182}$ This signifies that the outcome of intervention in conflict situations by the proposed panel can benefit from the procedures of the court in relation to enforcement of judgement if conflict participants so elect.

The legal status of the proposed panel can be boosted internationally through interaction with the umbrella body established in May 2013 by the AU Assembly which is known as the Pan African Network of the Wise (PANWISE). ${ }^{183}$ The PANWISE comprises the panel of the wise, similar structures within the Regional Economic Communities and all other African actors contributing to peace-making through preventive action and mediation. ${ }^{184}$ Its aim is to bring together mediation institutions and actors across the continent, with a view to building synergies

\footnotetext{
178 The Court of Appeal Rules, 2011, Order 16 Rule 1 Sub-rule 1.

${ }^{179}$ Id, Order 16 Rule 3(a).

${ }^{180}$ High Court of Lagos State (Civil Procedure) Rules 2012, Order 39, rule 4 (3).

${ }^{181}$ This is defined by the Latin maxim expressio unius est exclusio alterius and interpreted in Nawa v Attorney General of Cross Rivers State [2008] ALL FWLR (Pt. 401) 807 at 843, paras F- H

${ }_{182}$ Court of Appeal Rules 2011, Order 16 Rule 4.

183 Declaration on the Report of the Peace and Security Council on its Activities and the State of Peace and Security in Africa (Assembly/AU/Decl.1(XXI)), adopted by AU Assembly, Twenty-First Ordinary Session, 26 - 27 May 2013 , Addis Ababa, Ethiopia, at para 1.

${ }^{184}$ Ibid.
} 
among all concerned. ${ }^{185}$ Once established the proposed panel can seek admission and once admitted, share and benefit from experiences with similar institutions existing within the network of the PANWISE.

\section{CONCLUSION}

Violent conflicts associated with identities including religion, ethnicity, oil resource and indigene/settler distinctions continue to challenge the peace and stability of Nigeria. Such conflict scenarios include the Boko Haram, Niger Delta and Jos-Plateau crises to mention a few. The responses of the government to tackle this development are devoid of normative basis which can motivate consistent conflict intervention and foster peace. This is well evident in the 1999 Constitution which though provides for peace as a common aspiration and makes provisions for the role of court, fails to create a mechanism to address identity related violent conflicts, a recurring feature of national life. The article makes a case for the creation of a panel of the wise in the constitution of Nigeria and explores key considerations in terms of the composition, functions and legal status of intervention in establishing the panel. Such a mechanism fits into theoretical discussion on the concept of "constitutional essentials" and is supported by trend national constitutions of African states as well as regional and sub-regional instruments which can shape key considerations in terms of composition, functions and legal status of intervention in establishing the panel.

The composition of the panel can follow the example of limited membership as shown in the practices of AU panel of the Wise and COMESA with due regard for six-geopolitical zones, integrity, gender and religion considerations. Its impartiality and security can be ensured by the inclusion of civil society in the appointment and removal of members and allowing for a renewable tenure of five years. The proposed panel should be able to intervene into identity based conflicts on its own initiative, when invited by parties, or requested to do so by a member of the civil society. While the interventions by the panel is recommendatory and non-binding, the legal status of the intervention of the panel in relation to the court can be interdependent allowing the two institutions to benefit from the process of each other. That such a synergy is possible is visible in the provisions of rules of court such as the 2012 Lagos State High Court Rules and the 2011 Court of Appeal Rules which allow significant space for intervention by alternative dispute resolution mechanisms to benefit from the enforcement proceedings of the court. A synergy with the umbrella body known as PANWISE developed under the AU PSC platform can also boost the legal status of the panel internationally. The establishment of a panel of the wise as an essential in the constitution will make a difference in the approach towards conflict management and fostering of peace in Nigeria.

${ }^{185}$ Ibid. 